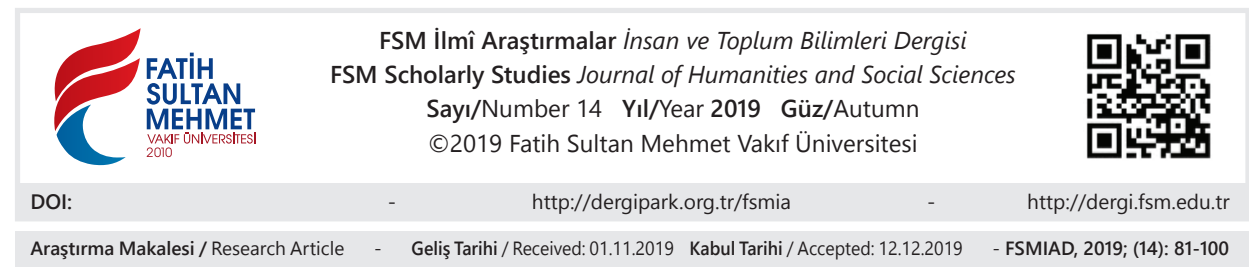

\title{
Yahya Kemal'in 1925 Türkiye-Suriye Tahdid-i Hudut Komisyonu Üyeliği ve Bu Vazife Dolayısıyla Ankara'ya Gönderdiği Raporlar
}

Mehmet Samsakçı*

$\ddot{\mathbf{O z}}$

1902'de memleketi olan Üsküp'ten tahsil maksadıyla İstanbul'a gelen fakat çeşitli sebepler yüzünden herhangi bir okula kaydolamayan Yahya Kemal hemen bir y1l sonra Paris'e gider. Burada bir sene devam ettiği ve Fransızcasını geliştirdiği Collége de Meaux ve Ecole Libre des Sciences Politiques'in "Dış Siyaset" bölümlerinde okur. Bu iki okuldan da mezun olamamasına, özellikle Paris'teki son yıllarda daha çok edebiyatla ilgilenmesine rağmen aldığı bazı dersler, sohbetlerinde bulunduğu, konferanslarına gittiği bazı büyük âlimler, hepsinden önemlisi derin ve dikkatli okumaları sayesinde Yahya Kemal sağlam bir tarih, felsefe, kültür ve medeniyet perspektifi edinmiştir. 1912'de Türkiye'ye döndükten çok kısa bir süre sonra da dersleri, sohbetleri ve yazılarıyla bu donamımı açığa vurur. Mütareke döneminde, işgal İstanbul'unun zor şartları altında da olsa Kuva-yı Milliye lehinde neşrettiği yazılar ise Yahya Kemal'in sadece tarih değil, sağlam bir diplomasi bilgisine de sahip olduğunu gösterir. Mustafa Kemal Paşa başta olmak üzere, Millî Mücadele döneminde Anadolu cephesi tarafindan okunan bu yazıların da tesiriyle Yahya Kemal Cumhuriyet'in ilânından sonra Urfa Mebusluğuna getirilir ve bu ilk mebusluğu zamanında Türkiye-Suriye Tahdid-i Hudut Komisyonu'na önce âzâ, sonra başkan olur.

Doç. Dr., İstanbul Üniversitesi Edebiyat Fakültesi Türk Dili ve Edebiyatı Bölümü, İstanbul/

Türkiye, samsakci@istanbul.edu.tr, orcid.org/0000-0002-7855-6557 
Bu çalışmada, Yahya Kemal'in bu komisyon üyeliği zamanında, sınırın nereden çizileceği, çizilmesi gerektiği konularında Hariciye Vekâleti’ne gönderdiği ve daha önce herhangi bir çalışmada yayımlanmayan raporlar incelenecek ve yayımlanacaktır.

Anahtar Kelimeler: Yahya Kemal, Urfa mebusluğu, Türkiye-Suriye Tahdid-i Hudud Komisyonu.

\title{
Yahya Kemal's Membership of the Comission to Define Turkey-Syria Border in 1925 and His Reports Sent to Ankara Related to This Duty
}

\begin{abstract}
Yahya Kemal, who came to Istanbul from his hometown of Skopje in 1902 but failed to enroll in any school due to various reasons, went to Paris a year later. In Paris, he studied at the Collége de Meaux (where he studied for a year and developed his French) and Ecole Libre des Sciences Politiques "Foreign Policy". He was not able to graduate from either of these two schools, and he was more interested in literature, especially in Paris. But it is certain that Yahya Kemal acquired a solid perspective on history, philosophy, culture and civilization through some of the lectures he attended, some great scholars to whom he had conversations and listened to, and above all his deep and careful research. In 1912 he returned to Turkey and lessons, with chat and text has shared this knowledge and experience with the public. During the Armistice period, the articles he published in favor of the National Forces, albeit under the difficult conditions of the occupation of Istanbul, show that Yahya Kemal not only has a solid knowledge of history, but also a strong diplomacy. These articles of Yahya Kemal were read by the Anatolian front, especially Mustafa Kemal Pasha during the National Struggle. Yahya Kemal becomes a deputy of Urfa after the proclamation of the Republic with the influence of these writings. Yahya Kemal, Determination of the Turkey-Syria border in this period before a member of the Commission then appointed as chairman. In this study, the reports - which are unpublished in any study - sent by Yahya Kemal to the Ministry of Foreign Affairs on where to draw the border and when it should be drawn will be examined and published.
\end{abstract}

Keywords: Yahya Kemal, Urfa deputy, Determination of the Turkey-Syria Border Commission. 
1884'te, bugün Anavatan toprakları hâricinde kalan Üsküp'te doğan Yahya Kemal, 1902'te tahsil maksadıyla İstanbul'a gelmiş fakat yaklaşık bir y1llık bir ikametten sonra Paris'e gitmiş, 1912'ye kadar da Paris'te tarih ve siyaset öğrenimi görmüştür. Bu süre zarfinda Paris'teki Jön Türklerle de sık sık görüşen Yahya Kemal, tarih, milliyet ve siyaset gibi konularda onlardan ayrı bir yerde durmuş, onların dar ufuklu nazariyeleriyle tatmin olmamış, kendi tefekkürünü biraz da kendisi inşa etmiştir. Albert Sorel gibi büyük bir tarihçinin öğrencisi olan, konferanslarına devam eden, Camille Julien'in de "Fransiz milletini 1000 yılda Fransız toprağ yarattı" şeklindeki coğrafya ve tarihe istinat eden bir milliyet nazariyesini benimseyen Yahya Kemal, İstanbul'a, çok özgün bir tarih, siyaset ve milliyet perspektifi ile dönmüştür. Siyasî İlimler Mektebi'nden ya da başka bir kolejden diploma almamasına rağmen Yahya Kemal'in doğu ve batı tarihini, medeniyetini derinlemesine tetkik ettiği, yorumladığ bu arada da kendisine has bir Türk-İslâm nazariyesine sahip olduğu bilinen bir gerçektir.

Yahya Kemal, 1912'deki dönüşünden çok kısa bir süre sonra az sayıda neşrettiği şiir ve yazılarıyla fakat daha çok sohbetleri ve dersleriyle bu çok özgün tefekkürünü dişavurur. Meşrutiyet'ten hemen sonra İstanbul'a dönen, İttihat ve Terakki hükümetlerinde de çeşitli seviyelerde görev almış olan Paris aşinaları ya da yeni tanıştığı ricalin de tercihiyle Darüşşafaka, Medresetü'l-Vaizîn, Heybeliada Bahriye Mektebi gibi okullardan sonra Yahya Kemal'i Darülfünun Edebiyat Şubesi'nde müderris olarak görürüz. Mütareke'nin henüz ilk yıllarında evvelâ Garp Edebiyatı Tarihi, bilahare de Cenab Şehabeddin'den inhilâl eden Türk Edebiyatı Tarihi kürsülerinde dersler verir. Yine bu yıllarda, bazı şiir ve yazılarını neşrettiği - bir anlamda çıkardığı - Dergâh Mecmuası etrafında oluşan fikir ve sanat atmosferi, diğer yandan işgal İstanbul'undaki ağır sansüre rağmen edebiyat, tarih ve siyaset alanlarında, bugün çeşitli kitaplarının içeriğini oluşturan makalelerini neşreder. Bu yazılar, işgal altındaki şehrin okurlarına ufuk ve ümit verirken bir yandan da Anadolu'da mücadeleye moral katkı sağlar. Zira cephede savaşanlar da Yahya Kemal'in bu aktüel yazılarını imkân buldukça takip etmişlerdir. O kadar ki şairin kardeşi Reşad Beyatlı Atatürk'ün, bir musahabesinde Yahya Kemal'in yazılarının "İstiklâl Harbi'nde bir meş'ale gibi yandı̆̆ını" söylediğini nakletmektedir. ${ }^{1}$ Yahya Kemal, bugün Eğil Dağlar'da yayımlanmakta olan bu makale ve sohbetleriyle asırların örsünde dövülen ve yoğrulan Türk-İslâm zevkinin yaratıcı kabiliyetinin aksi olan Anadolu ve İstanbul'un neden Türklerde kalması gerektiğini ikna edici delillerle ortaya koyar.

1 “Yahya Kemal'in Hayatı", Yahya Kemal Enstitüsü Mecmuası, 1, haz. Nihad Sami Banarl, İstanbul, İstanbul Fetih Cemiyeti Yahya Kemal Enstitüsü Yayınları, 1959, s. 139. 
Yahya Kemal'in, söz konusu yazıları, konferansları ve derslerinde akseden bu geniş bilgi ve kültürü, O'na Cumhuriyet'in ilânı aşamasında ve Cumhuriyet Türkiye'sinde bazı bürokratik ve diplomatik vazifelerin kapısını açmıştır. Yahya Kemal'e Ankara tarafından tevdi edilen ilk vazife Lozan murahhaslığıdır ki bu heyete Matbuat Müşaviri olarak iştirak etmiştir. Yahya Kemal, Lozan görüşmelerinden sonra, heyetle beraber Eskişehir'e, oradan Ankara'ya gitmiş, bir ay kadar kalmış, oradan da İstanbul'a gelmiştir. ${ }^{2}$ Yukarıda belirtildiği üzere de Temmuz 1923 'te de Urfa Mebusu olarak tayin edilir. Darülfünun'daki görevinden de bu münasebetle istifa eder. 22 Mayıs 1926 tarihli istifa mektubundan öğreniyoruz ki Varşova Elçiliğine tayinine kadar bu ilk mebusluğu devam etmiştir. ${ }^{3}$

Yahya Kemal'in bu ilk parlamento tecrübesine dair bütün detayları bilmek mümkün değilse de buradaki en önemli vazifesinin Türkiye-Suriye Tahdid-i Hudut Komisyonu'ndaki âzâlığı olduğu kesindir. Meclisin bu devredeki 3. celsesinde, Cumhuriyet' in ilânından yaklaşık 2 ay önce ve henüz söz konusu komisyona üye değilken güney sınırımızla ilgili "muhtasaran bazı şeyler söyleyeceğini”" belirterek yaptığı mühim bir konuşması söz konusudur. Burada Yahya Kemal, henüz 1921'de yani Millî Mücadele devam ederken Fransızlarla imzalanan Ankara Antlaşması'ndaki bir hataya işaret eder ve sınırın "Lâzkiye'nin cenubundan" çizilmemekle yanlış yapıldığını, tabiatın dahi buna isyan ettiğini, Fırat'ın da Batı'daki Meriç gibi tabiî bir sınır teşkil edeceğini, bu sayede Diyarbekir, Siverek, Urfa, Mardin, Siirt ahalisi"nin anavatanda kalacağını belirtir. İskenderun ve Antakyalıların mustarip olmamalarını, bunun bir veda saati olmadığını, zamanı gelince o toprakların da anavatana ilhakının sağlanacağını belirterek konuşmasını bitirir. ${ }^{4}$ Hakikaten Millî Mücadele'nin en kritik aşamalarından birisinde, 1921'de imzalanan bu antlaşma, ordunun dikkatinin İstanbul, Bursa, İzmir ve Trakya'ya yöneldiği, yönelmesi gerektiği bir zamanda imzalanmış, büyük bir rahatlama sağlamıştır fakat birçok şehir ahâlisini de hüzne boğmuştur. Bazı noktaları tehir etmiş ya da muallakta bırakmıştır. Meselâ antlaşmanın 7. maddesinde "İskenderun mıntıkası için bir Usul-ı İdare-i Mahsusa tesis olunacaktır. Mıntıka-yı mezkûrenin Türk ırkından olan sekenesi harslarının inkişafı için her türlü teshilâttan müstefid olacaklardır. Türk lisanı orada mâhiyet-i resmiyeyi hâiz olacaktır"5 denmekte, 8 .

2 Kâzım Yetiş, Yahya Kemal I Hayatı, İstanbul, İstanbul Fetih Cemiyeti Yahya Kemal Enstitüsü Yayınlar1, 1998, s. 225-226.

3 a.g.e., s. 226.

4 Yahya Kemal Beyatlı, "Konferans ve Hitabeler", Mektuplar-Makaleler, İstanbul, İstanbul Fetih Cemiyeti Yahya Kemal Enstitüsü Yayınları, 1990, s. 255-256.

5 Türk-Fransız İtilâfnamesi (Ankara'da 20 Teşrinievvel 1337 / 1921 Tarihinde İmza Edilmiştir), s. 5. (Türkçe ve Fransızca neşredilmiş bu metinde basıma dair künye bilgileri yoktur.) 
maddede de "Hatt-ı hudud, İskenderun Körfezi üzerinde Payas mevkiinin hemen cenubunda olmak üzere intihap olunacak bir noktadan başlayacak ve kariben Meydan-ı Ekbez'e doğru gidecektir" " ifadelerine yer verilmektedir. Yahya Kemal'in bu Meclis konuşmasında, daha sonradan anavatana katılacak olan bu iki şehre atıf yapması bu sebeptendir.

Türkiye'nin güneydoğu illerinden birisi olan Urfa'nın milletvekilinin güney sınırı hakkındaki bu hassasiyeti göstermesi ve sürekli alkışlarla kesilen bu konuşmayı yapması şaşırtıcı değilse de Yahya Kemal gibi Rumelili ve bildiğimiz kadarıyla vatanın doğu ve güneyini daha önce görmemiş olan birisinin bu isabetli görüş ve tespitleri oldukça dikkat çekicidir. Muhtemeldir ki Yahya Kemal'in 1925 'te teşkil edilen ve genç Türkiye Cumhuriyeti'ni oldukça uğraştıran güney sınırı meselesinin hâlli maksadıyla teşkil edilen komisyona âzâ olarak seçilmesi de bu konuşmasıyla ilgilidir. Diğer önemli sebep de öteden beri bilinen siyasî ve tarihî birikimiyle selis Fransızcasıdır. Zira yüzyıllar boyunca Türk hâkimiyeti altında barış ve huzur içinde yaşayan Suriye toprakları konusunda Türkiye'nin muhatabı Fransa hükümetidir. 1. Dünya Savaşı'ndan sonra Osmanlı'nın terke mecbur kaldığı Suriye'ye o yıllarda tam mânâsıyla Fransa hâkimdir. ${ }^{7}$

Yine Reşad Beyatlı'nın verdiği bilgiye göre Yahya Kemal, "mebus seçildikten sonra Hatay'in bize ilhak mevzuunda vazifelendirilmiş, İstanbul'da Fransiz Büyükelçisi Mösyö Sarraut ile müzakereleri hazırladıktan sonra Hariciye kâtiplerinden Şahap Bey'le İskenderun'a giderek Fransiz Heyeti ile müzakere ve temaslarda bulunmuş, neticede vatanımıza mühim bir miktar arazi kazandırmakta rolü ve hizmeti olmuştur." " Nitekim Yahya Kemal de Nihad Sami Banarlı'ya anlattığ 1 hatıralarının bir yerinde "Payas İstasyonu'nun arkasındaki altı kilometre arazi ile Kilis'ten 13, Hassa'dan 18 Türk köyünün anavatana ilhakını" temin ettiğini söyler. ${ }^{9}$

6 a.g.e., s. 5.

7 Ayrıntılar için bkz. Mehmet Âkif Okur, "Emperyalizmin Ortadoğu Tecrübesinden Bir Kesit: Suriye'de Fransız Mandası”, Bilig - Türk Dünyası Sosyal Bilimler Dergisi, nr. 48, Kış 2009, s. 137-156.

8 a.g.e., s. 140. Reşad Beyatl1, aynı yazısında Ağabeyinin "Türkiye-Sirbistan sulhunun teâtisi için mebus ve Hariciye Encümeni Âzâsı sıfatıyla Belgrad" a da gönderildiğini belirtmektedir." s. 140 .

9 Nihad Sami Banarlı, Yahya Kemal'in Hatıralarl, İstanbul, İstanbul Fetih Cemiyeti Yahya Kemal Enstitüsü Yayınları, 1997, s. 58. 


\section{Yahya Kemal'in Tahdid-i Hudut Âzâlığına Tayini ve Güney Sınırı Hakkındaki Raporları}

25 Haziran 1925 tarihli belgede (Ek 1) görüleceği gibi Urfa Mebusu Yahya Kemal, başında Reisicumhur Gazi Mustafa Kemal'in bulunduğu İcra Vekilleri Heyeti'nin 24 Haziran 1925 tarihli toplantısında, "otuz lira yevmiye ve alelusul harcirahla", komisyona "siyasî murahhas" olarak tayin edilir.

Yahya Kemal'in, sınır meselesi üzerinde çalışmak için güneye ne zaman indiği malûm değildir. Bununla beraber bizzat kaleme aldığı "Senelerimin Bilânçosu”nda, 1923-1925 yıllarının karşısında “Ankara, İstanbul, Adana, Payas, Dörtyol" şehirlerine rastlanmaktadır. ${ }^{10} \mathrm{Bu}$ çalışmanın sonunda sunduğumuz eklerin ikincisinde görüleceği üzere "İskenderun'dan avdet" ettiği belirtilmekteyse de Yahya Kemal'in, "Senelerimin Bilânçosu”nda İskenderun'u saymamas1, o günlerde bu şehirde ikamet etmediğini düşündürmektedir. Aynı belgede "Adana'dan takdim ettiğim mektupta arz ettiğim veçhile" demesi ise O'nun evvelâ Adana'ya gittiğini, bir müddet orada çalışmalar yaptığını gösterir. Fakat Cumhurbaşkanlığı Devlet Arşivleri'nde Yahya Kemal'in Adana'dan merkeze gönderdiği bir mektuba rastlanmamaktadir.

Arşivdeki 3. belge Türkiye Cumhuriyeti Hariciye Vekâleti İstanbul Murahhaslığı'nın" “İstanbul Maslahatı"na hitaben yazdığı 2 Ağustos 1925 tarihli kısa yazıdır. Belgede "Suriye Tahdid-i Hudut Komisyonu'nun 20 Ağustos'ta işe başlamasının tensip edildiğinin Yahya Kemal Bey'e tebliğ buyrulması rica" edilmektedir. Komisyonun 20 Ağustos'ta işe başlamasının uygun görüldüğü, bir gün sonraki bir yaziyla "Büyükada'da Yat Kulüp’te Urfa Mebusu Yahya Kemal Beyefendi' ye" de bildirilir. (Ek 4) Fakat Yahya Kemal'in 18 Ağustos 1925 tarihli "şifreli" ilk raporu, (Ek 5) 20 Ağustos tarihinden önce güneye indiğini, konu hakkında Fransız delegasyonundan bazı zevatla konuştuğunu, kısaca komisyonun teşrik-i mesaisini beklemediğini belgelemektedir. Diğer bir ihtimal ise Yahya

10 a.g.e., s. 131.

11 Sovyetler, Gürcistan, Afganistan gibi bazı devletler, henüz Millî Mücadele devam ederken Ankara Hükümeti'yle diplomatik ilişkilerini Ankara'da açtıkları dış misyonlar marifetiyle sürdürmüşlerken, Cumhuriyet'in ilânından sonra dahi İngiltere ve İngiltere'nin tesiriyle Almanya, İtalya, Amerika, Japonya, Lehistan, Yunanistan, Yugoslavya gibi Fransa elçiliğini İstanbul'da tutma, Ankara'ya taşınmama noktasında direnç göstermiştir. Ankara Hükümeti de bu durum için geçici bir çözüm olarak, başında Adnan (Adıvar) Bey’in bulunduğu ve esas vazifesi "Cumhuriyet hariciyesinin temaslarını sağlamak" olan bir Dersaadet Murahhaslığı ihdas etmiştir. Ayrıntılı bilgi için bkz. Kemal Girgin, Osmanlı ve Cumhuriyet Dönemleri Hariciye Tarihimiz (Teşkilât ve Protokol), Ankara, Atatürk Kültür, Dil ve Tarih Yüksek Kurumu Türk Tarih Kurumu Yayınları, 1994, s. 121, vd. 
Kemal'e 20 Ağustos'tan önce çalışmaya başlamasının bildirilmiş olduğudur fakat elimizde belgesi yoktur.

Sol köşesinde "Delegation a Constantinople" anteti görülen bir kâğıda, İstanbul'da yazdığ 1 anlaşılan bu ilk geniş raporunda Yahya Kemal, Fransız Sefiri Sarraut ${ }^{12}$ ile görüştüğünü ve Sarraut'nun, Fransa'nın Suriye Valisi General Sarrail'den ${ }^{13}$ bir telgraf aldığını belirttiğini ve General'in "uzlaşmaz" bir tavır sergilediğini, ayrıca vazifesi sona ermek üzere olan Sarrail' in yerine geçecek yeni Suriye Valisi ile görüşülmesinin daha isabetli olacağını belirtmektedir. Ayrıca Hariciye Vekili'nin Musul'dan dönüşünde, İstanbul'dan geçerken (Fransız dış misyonunun henüz İstanbul'da olduğu yukarıda belirtilmişti) Mösyö Sarraut ile görüşmesini tavsiye etmektedir. Yahya Kemal, Sarraut'ya, Sarrail gibi “itilâf-giriz" birisi olan Miralay Maille'dan, istek ve taleplerini yumuşatmasını rica ettiğini de raporuna ekler ve Albert Sarraut'nun anlaşma konusunda gayretli olduğunu belirtir. Kısaca Yahya Kemal, Mösyö Maille ile görüşmeye devam etmenin bir faydası olmayacağını, biraz zaman kazanmak gerektiğini, zira Maille'ın, hükümetinden daha uzlaşmacı bir emir alabilmesinin ihtimal dâhilinde olduğunu sözlerine ekler. Son olarak da 20 Ağustos'ta, yani bu raporun kaleme alınmasından iki gün sonra müzakerelere başlanacağına dair Fransızlara bir bilgi verilmişse, bunun ertelenmesi gerektiğini, kendisinin de 20 Ağustos'la ilgili hiç kimseye bir şey söylemediğini belirtir. Görüldüğü gibi Yahya Kemal, meselenin henüz başlarında oldukça dikkatli, temkinli ve hassastır. Müzakerelerin öncesinde Fransız muhataplarının kişilik, tarz ve tutumlarını hemen anlamış, Türkiye'nin, kiminle, ne zaman, hangi konuları görüşmesi lâzım geldiğini hükümete bildirmiştir.

Yahya Kemal, bir sonraki raporunu, ilkinden yaklaş1k bir ay sonra kaleme alır. 14 Eylül 1925 tarih ve yine "Hariciye Vekâleti'ne" hitabıyla başlayan bu rapora (Ek 6) kadar O'nun komisyon üyeliği çerçevesinde neler yaptığını bilmiyorsak da, ilk raporda belirttiği şekilde, İstanbul'da bazı görüşmeler gerçekleştirdiği, bu yüzden de Adana ya da İskenderun'dan yeni bir rapor göndermediği sonucu istihraç olunabilir. Bu raporda, Fransızların "Şimâlî Suriye Müdafaa-i Hukuk

12 Sömürgeci politikaları ve radikal sosyalistliği ile tanınan Albert Pierre Sarraut, 1925-1926 yıllarında Fransa'nın Türkiye Büyükelçisi olmuştur. Fransa'nın 73. başbakanıdır. Ayrıntılı bilgi için bkz. https://www.britannica.com/biography/albert-sarraut

13 1. Dünya Savaşı'nda Fransız ordusunda kritik görevler almış ama bazı başarısızlıkları yüzünden çeşitli aziller yaşamış olan General Sarrail, 1920'lerin ortalarındaki Büyük Suriye İsyanlarının şiddetle bastırılmasında büyük rol oynamış, örneğin “Şam Bombardımanı” emrini vermiştir. Tahdid-i Hudut müzakereleri de tam bu yıllarda yapılmıştır. Sarrail hakkındaki en geniş etüt, Jan Karl Tanenbaum'un “General Maurice Sarrail, 1856-1929 The French Army and Left-Wing Politics, Unc Press Enduring Editions, 2011, s. 312) isimli çalışmasıdır. 
Komitesi” adıyla bir komite kurdurduklarını, bir beyanname dağıtmak suretiyle İslâmiyet'i, Şeyh Sait İsyanı'nı ve halife ailesini kullanarak, "anavatana iltihak etmek isteyen o mıntıka halkını" Türkiye aleyhine kışkırttıklarını haber verir. Daha fenası ise bu faaliyete Tahdid-i Hudut Komisyonu'nun Fransız üyelerinin de katılmalarıdır. Yahya Kemal, sonra sözü 1925 Suriye İsyanı'nın en önemli isimlerinden birisi olan Sultan el-Atraş'a ${ }^{14}$ getirir ve O'na Türkiye'nin gayr-i resmî olarak "ketum ve emin" bir adam göndermesinin yerinde olacağını bildirir. Zira el-Atraş'ın, o dönemde Suriye toplumları, dolayısıyla Fransa üzerinde etkisi söz konusudur ve Türkler lehinde hareket etmesi sağlanabilir.

Türkiye Cumhuriyeti Hariciye Vekâleti İstanbul Murahhaslığı tarafindan Ankara'ya, Hariciye Vekâleti'ne yazılmış olan 26 Eylül tarihli bir sonraki belge, Fransız Sefiri'nin Murahhaslığa gönderdiği ve kısa bir inkıtaa uğradığı anlaşılan müzakerelerin Ekim'de yeniden başlayabileceğini ve ülkeleri adına komisyona General Sarrail’ın Özel Kalem Müdürü Mösyö Desbordes ile Sefaret Müsteşarı Mösyö Brugere'in atandığını bildirdiği bir yazı üzerine kaleme alınmıştır. Bu arada Yahya Kemal'in de bu tarihten itibaren Tahdid-i Hudut Komisyonunun Reisi olduğunu görüyoruz. (Ek 7)

Bu yazıdan hemen 3 gün sonra Yahya Kemal'in, İstanbul'da kaleme aldığ 1 anlaşılan raporu gelir. Yahya Kemal, Fransız Sefiri Mösyö Sarraut ile görüştüğünü, Sarrut'nun, sürat ve sıhhat bakımından müzakerelerin bundan sonra ikisi arasında geçmesi gerektiğini söylediğini (zira General Sarrail ve emrinden çıkmayacağı tabiî olan Özel Kalem Müdürü'nün, ayrıca Miralay Maille'ın tutumları bellidir.) kaydeder. Sarraut, diğer delegelerin inatçı tutumlarını yumuşatma vaadinde de bulunmuştur. Açıkça görülmektedir ki asker delegeler, bürokrat ve diplomatlara göre daha uzlaşmaz bir tutum takınmaktadırlar. Yahya Kemal'in bu rapordaki en mühim meselesi, müzakerelerde sınırın nereden çizileceği, hangi hat ya da beldelerde 1srar edileceği konusudur. Payas-Çobanbey arası arazi konusunda bir tereddüdü bulunmayan Yahya Kemal, Türkiye'yi Musul'a bağlayacak yol noktasında nasıl hareket edeceğini bilemediğini, bu konuda emir beklediğini bildirmektedir. (Ek 8)

Tam bir hafta sonra Yahya Kemal, Ankara'ya yeni bir rapor gönderir. Aktardıklarına göre raporunu kaleme aldığı gün yine Albert Sarraut ile sınır konusunu görüşmüştür. Muhatab1, Türkiye'ye "verebileceği” bazı yerleri belirtmiş, bunlar-

14 Dürzi asıllı bir lider olan Sultan El-Atraş ve faaliyetleri hakkında bkz. Borisoviç Lutskiy, Arap Ülkelerinin Yakın Tarihi (16. Yüzyıldan 20. Yüzyıla), çeviren Turan Keskin, İstanbul, Yordam Kitap, s. 367; İzzettin Artokça, Ortadoğu'da Dürzîler, stratejik rapor 54, Türk-Asya Stratejik Araştırmalar Merkezi (Tasam), t.y. 
dan başka "hiçbir fedakârlıkta bulunmayacağını" söylemiş̧tir. Yahya Kemal'in pek çok raporunda belirttiği gibi mutedil bir kişiliği olan ama bu kez Miralay Maille'ın tesiri altında kaldığı anlaşılan Sarraut, Payas İstasyonu'nu, Türkiye'nin üzerinde tartışmadığı ve müzakerelere ait haritalarda "kırmızı ile işaretlediğì" Kilis'i, Nusaybin bahçeleri dediği sahayı “Türkiye'nin mevsum addettiği Roma yolu onlarda kalmak şartıyla" vermekte fakat o güne kadarki görüşmelerde Türkiye sınırları içerisinde kalacağ kararlaştırılmış olduğu anlaşılan Kızılkaya ve M1ğırtepe'yi istemektedir. Yahya Kemal, Türkiye'nin dört senedir kabul etmediği s1nırları şimdi de kabul etmeyeceğini kesin bir dille bildirdiğini aktarır. Sarraut "bir karış fazla yer vermeme" noktasında ısrarcıysa da müzakerelerin akametinden de endişelidir. Yahya Kemal, emir ve talimat beklediği hususunu arzla raporuna son verir. (Ek 9)

Yahya Kemal'in Ankara'ya gönderdiği son ve belki en ciddî ve net rapora (Ek 10) göre hakikaten taraflar tam bir hafta sonra yani 12 Ekim'de son bir görüşme yaparlar. Yahya Kemal'in müşahedesine göre Sarraut daha mülayimdir, Kilis'te 15 köyün halkının Türk ve mülklerin Türklere ait olduğu ispatlanırsa konuyu Paris'e bildireceğini ama General Sarrail'ın siyaseten Fransa'da sıkışık bir vaziyette olduğunu yani bu "taviz"in verilemeyebileceğini belirtir. (Yahya Kemal hemen harekete geçmiş “İstanbul Tapu Müdüriyeti'nden, on beş köyün tapularının kayıtlarını” istemiştir.) Türkiye'nin bazı sınır ve beldeleri tartışmayacağını ayrıca da iki komisyonunun şimdiye kadarki mesaisinin "istihzarî", bugünkü tabirle "taslak" olduğunu, asıl görüşmelerin ise daha resmî ve diplomatik usullerle yapılacağını belirttiğini kaydetmiştir.

Yahya Kemal'in bu çabaları sayesinde sınırın teşkili konusunda yol alınmışsa da komisyon meseleyi hâlledememiştir. Fransızlar şiddet yanlısı General Sarrail'i görevden almışlar, onun yerine Henry de Jouvenel'i 8 Kasım 1925'te Suriye'ye ilk sivil komiser olarak atamışlardır. ${ }^{15}$ (Fakat kısa bir süre sonra Jouvenel'in yerine de Mr. Henry Ponsot atanmıştır.) Sürecin nasıl devam ettiğini Müzehher Yamaç şöyle özetler: "Nihayet Türk ve Fransız hükümetleri doğrudan diplomatik girişimlerde bulunarak, 18 Şubat 1926 tarihli "Dostluk ve Iyi Komşuluk” sözleşmesini imzaladılar. Anlaşmayı Suriye adına Fransa'nın Ankara Büyükelçisi Albert Sarraut ve Türkiye adına Dışişleri Bakanı Tevfik Rüştü Aras imzalamışladır. Beş protokol ve bir mektubun ekli olduğu antlaşma ile Türkiye-Suriye sinırı ile ilgili meseleler açıklığa kavuşturulmuştur."

15 Müzehher Yamaç, "Fransız Diplomatik Belgelerinde Türkiye-Suriye Sınır Sorunu (1918 -1940), Belleten, cilt LXXXII, nr. 295, Aralık 2018, s. 1158-1159. 
Fakat bilindiği gibi bu antlaşma masadaki sorunları tamamen ortadan kald1ramadığı gibi bazı çatışma noktalarını da beraberinde getirecek ve Türkiye'nin güney sınırının tam mânâsıyla halli için 1939 yılını beklemek gerekecektir.

\section{Sonuç}

20 Ekim 1921'de, henüz Millî Mücadele devam ederken, Fransa ile Türkiye Büyük Millet Meclisi hükümeti arasında imzalanan Ankara Antlaşması, iki ülke arasındaki savaş durumunu sona erdirmiş fakat Türkiye-Suriye sınırının nereden çizileceği konusunu muallakta bırakmıştır. O yıllarda Suriye'de bir "manda" rejimi tesis etmiş olan Fransa, bu antlaşmada bugün Türkiye Cumhuriyeti sınırları içinde olan pek çok şehri dışarıda bırakmış, o yıllarda Batı cephesinde savaş devam ettiği için de Türkiye bu şehirlerle ilgili adımları hemen atamamıştır. 1925'e gelindiğinde ise Fransa ile Türkiye Cumhuriyeti, sınır meselesinin halli için bir "Tahdid-i Hudut Komisyonu" kurar. Komisyonun en önemli Fransız üyesi, Fransa Elçisi Albert Peirre Sarraut ve Türk üyesi de Urfa Mebusu Yahya Kemal'dir. Yahya Kemal, konuyu yerinde incelemek için Kilis ve civarında incelemeler yapmış, o günlerde söz konusu bölgede kimlerin ne durumda olduklarını, Türkiye'nin nasıl hareket etmesi gerektiğini, Fransızların yöre halkını Türkiye aleyhine nasıl kışkırttıklarını raporlarında belirtmiştir. Türkiye-Suriye sınırı meselesi bu komisyonun çalışması sonucu da çözüme kavuşmayacaksa da bu gayretleri neticesinde Yahya Kemal kendi tabiriyle "Payas Ístasyonu'nun arkasindaki altı kilometre arazi ile Kilis 'ten 13, Hassa'dan 18 Türk köyünün anavatana ilhakını" temin etmiştir. Çalışmada Yahya Kemal'in bu komisyona atanması süreci söz konusu edilmiş ve Hariciye Vekâleti'ne gönderdiği, bugün Cumhurbaşkanlığı Devlet Arşivleri'nde bulunan ve daha önce gün yüzüne çıkmamış olan raporlar Lâtin alfabesine aktarılmak suretiyle tam metin olarak verilmiştir. 


\section{Ek 1}

Başvekâlet

Kalem-i Mahsus Müdiriyeti

Aded 2156

\section{KARARNAME}

Urfa Mebusu Yahya Kemal Bey’in, Otuz Lira yevmiye ve alelusûl harc-1 rahla Suriye Tahdid-i Hudud Komisyonu nezdine siyasî murahhas olarak tayini ve harc-1 rah ve yevmiyenin Hariciye Vekâleti bütçesinin fi'l-i mahsusuna itâsı İcra Vekilleri Heyeti'nin 24 Haziran 341 tarihli içtimaında karar-gîr olmuştur.

24 Haziran $341^{17}$

Türkiye Reis-i Cumhuru

Gazi M. K.

Vekillerin imzaları

$30-18-1-1,14 / 41 / 8$

\section{Ek 2}

\section{Hariciye Vekâletine}

İskenderun'dan avdet eden Yahya Kemal Bey’in maruzatı ber-vech-i âtîdir:

Adana'dan takdim ettiğim mektupta arz ettiğim veçhile komisyonumuzun Kilis'te içtima edeceği tarihi tayin etmek, re'y-i devletlerine merhundur. Musul meselesinin alacağı şekle mukarrer olduğu üzere intizar ederek içtima tarihi arzu buyrulduğu derece temdit olunabilir. Ancak bu tarihin şimdiden iş’ar edilebileceğini İskenderun' da bulunduğum zaman Miralay Maille'ya vaat etmiştim. $\mathrm{Bu}$ hususu, Halep’te bulunan Miralay’a iş’ar etmek üzere emr-i devletlerine muntazırım.

HR.IM / 249 / 95 / 1-2

1724 Haziran 1925

$18 \quad 28$ Temmuz 1925 


\section{Ek 3}

\section{İstanbul Maslahatına}

Suriye Tahdid-i Hudut Komisyonu'nun 20 Ağustos'ta işe başlamasını tensip ettiğimizi Yahya Kemal Bey’e tebliğ buyrulmasını rica ederim.

$2 / 8 /(13) 41^{19}$

Tevfik Rüştü

Türkiye Cumhuriyeti

Hariciye Vekâleti İstanbul Murahhaslığı

2 Ağustos (1)341

HR.IMM. 23 / $20 / 01$

\section{Ek 4}

\section{Büyükada'da Yat Kulüp'te Urfa Mebusu \\ Yahya Kemal Beyefendi'ye}

Hariciye Vekâlet-i celilesinden vârid olann 2 Ağustos 341 tarihli 1667 numerolu telgrafnamede Suriye Tahdid-i Hudut Komisyonu'nun 20 Ağustos'ta işe başlamasının tensip edildiği iş'ar olunmaktadır. Bilvesile teyid-i ihtirâmât olunur efendim.

$\begin{array}{lll}\text { Umumî numero } & : 11619 \\ \text { Hususî numero } & : 295 & \\ \text { Tarih } & & : \text { 3 Ağustos 3410 }\end{array}$

HR.IM. $153 / 20 / 02$ 


\section{Ek 5}

\section{Hariciye Vekâlet-i Celilesine}

\section{Şifre telgraf}

Fransa Sefiri Mösyö Sarraut, General Sarrail'den Suriye hudutlarımız işine dair telgraf almış. Bu telgraf üzerine benimle görüşmeyi talep etti. Bir saat görüştüm. General Sarrail, itilaf-giriz olan Miralay Maille'ın müddesasını aynen tebliğ ederek o derece mutedil olan mütâlaamızı "şedit" sıfatıyla tavsif ettikten başka karşılıklı arazi muvazaasına giremediğimizi, esas müzakereye muhalif gibi göstermektedir.

Mösyö Sarraut'ya, hükümetimizin Fransa ile anlaşmaya meyyal olduğunu, metâlibimizin Ankara İtilâfnamesi'nin ruh-1 ...' den ayılmadığını, Fransız Hükümeti'nin birçok defalar vaat ettiği geniş bir müsaadekârlıkla düşünüldüğü takdirde bu meselenin bir hamlede halledileceğini, binaenaleyh Miralay Maille'ın müddeasını tadil ettirmek için teşebbüste bulunmasını rica ettim.

Mösyö Sarraut, Paris'e yazacağını ve bir itilaf zemini bulmaya çalışacağını vaat etti. İkinci bir görüşmemizde de yazdığını söyledi.

Bugünkü vaziyette kanaatim hudut müzakeresini zât-1 âlilerinin Musul işinden avdeti zamanına kadar ta'lik etmektir. Bu fâsıla esnasında zât-1 âlilerinin İstanbul'dan geçerken bendenizle beraber Mösyö Sarraut'yu görmesi ez-her cihet faideli olacağı gibi yakında değiştirileceği zannolunan General Sarrail'in yerine gelecek vâli-yi umûmînin kim olacağını öğrenmek ve o zat ile de Paris'te Fethi Bey’i görüştürmek mütalâaasındayım.

Aksi hâlde şimdi hudutta Miralay Maille ile tekrar müzakereye başarsak mumaileyh eski müddeasını serd edecek ve esas müzakere ittihaz etmek istediği karşılıkla arazi tefvizi bahsini çıkaracak ve müzakereyi yine akāmete duçar edecektir. İskenderun'a teması bugün bizi arzu buyurduğunuz müsait vaziyette bulundurmakta ve istediğiniz vakti kazandırmaktadır. Zât-1 âlîlerinin ve Mösyö Sarraut'nun yeni bir teşebbüsleriyle yeni bir zemin-i itilâf hazırlandıktan sonra Miralay Maille, hükümetinden yeni bir talimat alırsa, bu işin halledilmesine ümit vardır. Komisyonumuzun reisi Abdi Bey’le müştereken kanaatimiz bu merkezdedir.

Binaenaleyh 20 Ağustos'ta tekrar müzakereye girişileceği hakkında Vekâlet-i Celilece Fransizlara şayet bir tebliğ vâki oluşsa bunun şimdilik mümkün olamayacağını ve müzakerâta biraz teehhürle bu tarihten sonra başlanılabileceği hakkında lâzım gelenlere iş’ârât-1 telgrafiyede bulunulması müreccahtır. Ben işbu 
20 Ağustos tarihi hakkında kimseye iş'âr-1 keyfiyet etmemiştim. Emr ü re'y-i devletlerinin iş’ârına muntazırım.

Yahya Kemal

$18 / 8 /(13) 41^{21}$

\author{
HR. IM. $250 / 27 / 1$
}

\title{
Ek 6
}

\section{Hâriciye Vekâletine}

Yahya Kemal Bey'in maruzâtı ber-vech-i âtidir

Son günlerde Fransızlar "Şimâlî Suriye Müdafaa-i Hukuk Komitesi” namıyla bir komite icat etmişler ve bu komite namına Suriye'de kalan köylerimizde bir beyanname dağıtmışlar ve Anavatana iltihak etmek isteyen o mıntıka halkını Cumhuriyetten tebrid etmek kastıyla tahrikâta girişmişlerdir. Bu beyannamede vatanımızda din-i Muhammedî'nin mahvedildiğinden, Halife ailesinin hakaret gördüğünden, bu sebeple Suriyelilerin ve bilhassa Kürt Dağı'ndaki Kürtlerin milliyetperverlerimizi daima tel'în edeceğinden, Kürdistan'a sevk edilmiş askerimizin öldürüldüğünden, maarif ve tayyare ianesi namıyla cebrî ianeler toplandığından İstiklâl Mahkemeleri’mizin başta bulunan birkaç kişinin menfaatine hizmet ettiğinden ve halkın zararına zengin olmaya çalıştığından, cenuptaki Türk köylerini istemekten maksadımızın oradaki halktan para ve intikam almak olduğundan bahseden şenî satırlar vardır.

Birer sureti Dâhiliye ve Erkân-1 Harbiye'ye takdim olunan bu beyannamenin metnini nazar-1 dikkat-i devletlerine arz ederim. Bu tahrikât, Tahdid-i Hudut Komisyonu'na memur olan Fransız zâbitleri tarafindan icra edilmektedir.

Suriye'nin bugünkü hâd derecede buhranlı vaziyetinden istifade etmek için ittihaz edilmesi lâzım gelen bir tedbiri re'y-i devletlerine arz ederim:

Son günlerde Şam üzerine El-Atraş'ın şedit ve istiklâl-perverâne beyânatı Suriye'nin Müslüman tabakalarını harekete getirmektedir. El-Atraş'ın nezdine mücerreb, ketum ve emin bir adamımız gayr-i resmî mâhiyette gönderilirse ve bu zâtın irşâdâtı ile El-Atraş Suriye'de kalan Türklerin istihlâsı lehinde beyânatta bulunursa bugünkü ahvâl ve ....'a göre fevkalade icra-yı tesir edeceğini, Fransızları lehimizde göstereceğini, hudut işimizin hâlline yardım edeceğini kaviyyen 
zannederim. Bu tedbirin bu suretle ittihaz edilmesinin Fransa ile olan münasebât-1 resmiyemizi idlâl etmeyeceği kanaatindeyim. İsmet ve Fevzi Paşalar bu işe memur edilecek mürerreb zâtı intihap, tayin ve sevk edebilirler. Bu tedbir ile Ankara'nın füsunkâr tesiri Cebel-i Duruz'da kendisini hissettireceği gibi Fransızların cenup hududundaki tahrikâtına karşı bir mukabele-i bi'l-misilde bulunmuş oluruz.

İfâ-yı muktezâsı re'y-i devletlerine menuttur.

Yahya Kemal

$14 / 9$ ( (13)4 $41^{22}$

HR. IM. $250 / 86$

Ek 7

Türkiye Cumhuriyeti Hariciye Vekâleti

İstanbul Murahhaslığı

\section{Hariciye Vekâleti'ne}

Türkiye-Suriye hudutlarının tahdidi zımnındaki müzâkerâtımıza memur olduğu ve bir aydan beri munkatı olan müzâkerâta yeniden başlanabilmesi için Türk Heyeti Reisi Yahya Kemal Bey'in münasip göreceği mahalde Teşrinievvel'in ${ }^{23}$ ibtidasından itibaren ilk içtimaın akdedilebileceği ve refakatine General Sarrail Bey'in kalem-i mahsus müdürü Mösyö de Desbordes İle Sefaret Müsteşarı Mösyö Brugere'in memur edildiğini Fransız Sefiri be-takrir bildirmektedir. Tayin olunduğunun bir an evvel tebliği rica olunur efendim.

Umumî numero

Hususî numero

Tarih

\section{HR.ìM.160/47/1}

$: 1201$

: 341

$: 26 / 9 /(13) 41^{24}$

2214 Eylül 1925

23 Burada bir zühul söz konusudur çünkü zikredilmesi gereken ay Teşrinievvel değil, Teşrinisani olmalıdır zira bu yazının kendisi 26 Eylül tarihlidir. Ayrıca Fransız sefirin İstanbul Murahhaslığı'na gönderdiği mektupta da (Cumhurbaşkanlığı Devlet Arşivleri, HR.İM. 160/47/2) "Partir Du Ler Octobre" yani “Ekim başı" ifadesi yer almaktadır. Bu mektubu bu çalışma için Türkçeye çevirme nezaketinde bulunan Prof. Dr. Nedret (Öztokat) Kılıçeri’ne çok teşekkür ederim. (M.S.) 


\section{Ek 8}

\section{Hâriciye Vekâleti'ne}

Yahya Kemal Bey’in maruzatı ber-vech-i âtîdir

Bugün Fransa Sefiri Mösyö Sarraut ile görüştüm. Suriye hududumuz meselesini en kısa ve doğru yoldan hâlledebilmek için müzâkerâtın ikimiz arasında cereyan etmesi takarrur etti. İlk defa Perşembe günü saat dörtte Beyoğlu'ndaki Fransa Sefarethanesi'nde ikimiz müzakereye başlayacağız. Mösyö Sarraut bugünkü temasta metâlibimize müsaadekâr ve işi bitirmeye hâhişkâr göründü.

Bu akşam General Sarrail'i temsil etmek vazifesiyle gelen Mösyö Desbordes Rexes ve Miralay Maille İstanbul'a muvasalat ediyorlar. Mösyö Sarraut beyan etti ki Miralay Maille'ın bu başlayacağımız müzakerâttaki vazifesi sırf istişârî mahiyette olacaktır. Mösyö Sarraut Miralay Maille'in metâlibimize karşı gösterdiği taannüdü tadil edeceğini vaat ediyor.

Payas'tan Çobanbey'e kadar olan kısım hakkında evvelce telâkki ettiğim evâmir-i talimat dâhilinde hareket edeceğim. Lâkin hududun şark müntehasında, bizi Musul'a isâl edecek olan Cizre - Nusaybin arasındaki sahaya dair ne suretle hareket edeceğimi Heyet-i Vekile'den istizan ederim. Musul işiyle alâkadar olan bu nâzik nokta hakkında emr-i devletlerine muntazırım. Başlayacağımız müzakerâtın şimdilik yalnız Payas - Çobanbey arasındaki sahaya tahsisini talep etmemiz mümkün ise de Mösyö Sarraut tarafından Cizre - Nusaybin bahsinin açılabilmesi ihtimalinin karşısında ihtiyar edeceğimiz tarz-1 hareketin tespit edilmesi re'y-i devletlerine menuttur efendim.

Yahya Kemal

Nusret

$29 / 9 /(13) 41^{25}$

HR.IM. 250/112 
Ek 9

\section{Hariciye Vekâleti'ne}

Yahya Kemal Bey'in maruzatı ber-cevh-i âtîdir

Bugün saat on birde Mösyö Albert Sarraut ile Suriye hududu işini müzakere ettik.

Mösyö Sarraut, pazarlık usulünden ârî olarak hadd-i aza mî terk edebileceği noktaları tasrih etti ve bundan başka hiçbir fedakârlıkta bulunmayacağını söyledi.

Mösyö Sarraut Payas istasyonunu veriyor, "Kilis'in bahçeleri” dediği ve dört seneden beri teklif olunup da kabul edemediğimiz ve müzakereye ait haritalarımızda kırmızı ile işaret olunan sahayı veriyor, Nusaybin bahçeleri dediği sahayı, bizim mevsum addettiğimiz Roma yolu onlarda kalmak şartıyla, veriyor. Bizden de Kızılkaya ve Mı̆̆ırtepe'yi istiyor.

Sefir-i müşarünileyh zât-1 devletleriyle görüştüğü zaman müzakerenin en esaslı noktası olan Kilis etrafındaki metâlibimizde itilâf-kâr davranmış iken âhiren Miralay Maille'ın tesirâtı ile musırr hareket etmekte olduğunu tahmin ediyorum.

Kilis'te hadd-i asgarî olan metâlibimizden feragat edemeyeceğimizi ve dört seneden beri teklif olunup da tarafimızdan reddolunan hattı şimdi kabul edemeyeceğimizi ve Kızılkaya ile Mığırtepe hakkında taahhüt altına girilmeyerek hükümetin nokta-i nazarını istizan edeceğimi beyan ettim. Müzakerenin edille ve müdafaa kısmını daha mufassal olarak takdim edeceğim. Lâkin hulâsası budur.

Müzakereyi altı gün yani gelecek Pazartesi gününe kadar talik ettik. Hâs1 ettiğim intibaya göre Mösyö Sarraut fazla bir karış bir yer veremeyeceğini kat'̂̂ ve azimkârâne bir lisanla beyan etmekle beraber bu müzakerenin de neticesiz kalması ihtimalinden çekinmektedir.

Evâmir ve talimât-1 devletlerine muntazırım efendim.

$6 / 10 /(13) 41^{26}$

HR.IM. 250/127 


\section{Ek 10}

\section{Hâriciye Vekâleti'ne}

1. Mösyö Sarraut son mülâkatımızda geçen günkü musırrane ve kat'î müddeasından farklı ve mülayim bir müddea dermeyan etti. Aynen dedi ki: "Kilis'in cenubunda talep ettiğiniz on beş köydeki halkın aslen Türk ve emlâkin Kilis Türklerine ait olduğuna dair vesâik-i resmiyeye müsteniden kanaat hâsıl edersem kanaatimi sarahatle Paris'e telgrafla bildireceğim. Ve bu köyleri size vereceğim." Mösyö Sarraut Kilis cenubundaki metâlibimize karşı General Sarrail'in bu aralık Fransız meclisindeki muhalefet ittifakına hedef olduğunu ve bize verilecek bir taviz vesilesiyle re's-i kârdaki hükümetin sarsılması ihtimalini mazeret makamında serd etmektedir.

2. Mösyö Sarraut'nun dermeyan ettiği son müddea üzerine kendisine kat'î bir kanaat bahşedecek vesaiki toplamaya başladım. İstanbul Tapu Müdüriyeti’nden, on beş köyün tapularının kayıtlarını çıkartıyorum. Hak ve adle müstenit olan iddiamızı bir defa da bu suretle ispat edeceğiz.

3. Şifrede üç numerolu emr-i devletlerinizi Mösyö Sarraut'ya tebliğ ettim. Kilis'te hadd-i asgarî metalibimizin tahakkukunda eskiden teklif olunup kabul edemediğimiz bir hattın tekrar teklif edileceğini hatırımızdan geçirmediğimizi ve kendilerine zât-1 devletlerinin mühim teshilâta muntazır bulunduğunu söyledim. Tebliğim hüsn-i tesir hâs1l etti.

4. Bugüne kadar olan mülâkatlarımızın istihzârî mahiyette olduğunu ve tarafeyn arasında bir zemin-i takarrub hâsıl olduktan sonra konferansın mutad ve usul veçhile murahhaslığımız dairesinde küşad ve kontrando tutulmak suretiyle tespit edileceğini ve celselere sira ile tarafeynin riyaset edeceğini ve müzakereyi birkaç celsede ikmal etmeye çalışacağımızı ifade ettim. Teklifimizi kabul ve hüsn-i telâkki etti. Bugünkü mesaimizin en müsskül nokta olan Kilis bahsinde bir anlaşmaya müncer olmasına çalışmaktan ibaret olduğunu söyledi. İhrirâmât. 


\section{Kaynakça}

Artokça, İzzettin, Ortadoğu'da Dürzîler, stratejik rapor 54, Türk-Asya Stratejik Araştırmalar Merkezi (Tasam), t.y.

"Yahya Kemal'in Hayat1", Yahya Kemal Enstitüsü Mecmuası, 1, haz. Nihad Sami Banarlı, İstanbul, İstanbul Fetih Cemiyeti Yahya Kemal Enstitüsü Yayınlar1, 1959.

Banarlı, Nihad Sami, Yahya Kemal'in Hatıraları, İstanbul, İstanbul Fetih Cemiyeti Yahya Kemal Enstitüsü Yayınları, 1959.

Beyatl1, Yahya Kemal, "Konferans ve Hitabeler", Mektuplar-Makaleler, İstanbul, İstanbul Fetih Cemiyeti Yahya Kemal Enstitüsü Yayınları, 1990.

Girgin, Kemal, Osmanlı ve Cumhuriyet Dönemleri Hariciye Tarihimiz (Teşkilât ve Protokol), Ankara, Atatürk Kültür, Dil ve Tarih Yüksek Kurumu Türk Tarih Kurumu Yayınları, 1994.

Lutskiy, Borisoviç, Arap Ülkelerinin Yakın Tarihi (16. Yüzyıldan 20. Yüzyıla), çeviren Turan Keskin, İstanbul, Yordam Kitap, 2011.

Okur, Mehmet Âkif, "Emperyalizmin Ortadoğu Tecrübesinden Bir Kesit: Suriye'de Fransız Mandası”, Bilig - Türk Dünyası Sosyal Bilimler Dergisi, nr. 48, Kış 2009.

Tanenbaum, Jan Karl "General Maurice Sarrail, 1856-1929 The French Army and Left-Wing Politics, Unc Press Enduring Editions, 2011.

Türk-Fransız İtilâfnamesi (Ankara'da 20 Teşrinievvel 1337 / 1921 Tarihinde Imza Edilmiştir)

Yamaç, Müzehher, "Fransız Diplomatik Belgelerinde Türkiye-Suriye Sınır Sorunu (1918 -1940), Belleten, cilt LXXXII, nr. 295, Aral1k 2018.

Yetiş, Kâzım, Yahya Kemal I Hayatı, İstanbul, İstanbul Fetih Cemiyeti Yahya Kemal Enstitüsü Yayınları, 1998.

https://www.britannica.com/biography/albert-sarraut 
